\title{
Tren Bisnis Tour Ke Tiongkok
}

\author{
CITRA AYU NOVITASARI, PANCA NUGRAHA \\ Diploma Bahasa Mandarin, Sekolah Vokasi, Universitas Gadjah Mada \\ citraayu@ugm.ac.id,panca_ugm@yahoo.com
}

\begin{abstract}
In recent years, several cities in Indonesia have been rife with the business tour to China. The purpose of this business tour is to survey and analyze wholesale market and factories in China. The cheap goods from China is the main reason for the beginners and mid-sized businesman, online and offline begin to try to follow this tour. The number of enthusiasts makes more and more individual or tour agent who offer services for tour business assistance to China. This is a new opportunity for tour and travel business in Indonesia. The purpose of this study is to know the trend of tourism business or business tour in Indonesia today.

Keywords:

Business Tour, China Tourism, Tourism Market, Business Trends, Tour and Travel
\end{abstract}




\section{Pendahuluan}

Pengertian tour adalah perjalanan wisata dengan tujuan bersenang-senang, mengunjungi berbagai kota, tempat hiburan, tempat yang menarik, situs sejarah, dan sebagainya. (Pendit, 2005:555). Menurut Kamus Besar Bahasa Indonesia disebutkan wisata adalah bepergian bersama-sama (untuk memperluas pengetahuan, bersenangsenang, dan sebagainya). Sementara itu, bisnis adalah usaha komersial dalam dunia perdagangan; bidang usaha; usaha dagang.

Bisnis tour bisa dikatakan sesorang yang melakukan perjalanan bukan dengan tujuan utama berwisata, namun terdapat tujuan lain yaitu berbisnis. Terkait hal ini misalnya melakukan riset pasar dan analisis produk di Tiongkok dan membandingkannya dengan pasar di Indonesia baik dari segi harga, kualitas dan intensitas kebutuhan konsumen terhadap suatu barang.

Saat ini perekonomian Tiongkok mempunyai arti penting di seluruh dunia baik dalam barang-barang produksi manufaktur, jasa finansial, dan mata uang serta suku bunga, pengaruh Tiongkok tidak terelakkan. (Mitler, 2011:158)

Tiongkok merupakan negara terpadat nomor satu di dunia. Seiring laju penduduknya yang pesat juga dibarengi dengan tingkat pertumbuhan ekonominya yang sangat cepat. Hal itu dapat terlihat dari perkembangan dan pembangunan kota-kota di seluruh wilayah Tiongkok. Pertumbuhan ekonomi ini tentu menjadi salah satu magnet kuat yang menarik negara-negara di dunia untuk berinvestasi maupun bekerjasama dengan Tiongkok.

Kota Guangzhou, Shenzhen dan Shanghai merupakan contoh kota yang dipenuhi dengan investor asing serta banyaknya anak muda Tiongkok dari berbagai daerah yang mengadu nasib di kota tersebut. Shanghai adalah salah satu kota terbesar di dunia dan merupakan pusat keuangan internasional. Guangzhou sejak dulu menjadi kota bisnis di Tiongkok, sedangkan Shenzhen merupakan sebuah kota kecil yang berubah menjadi kota modern dengan pembangunan paling cepat di Tiongkok.

Sekitar tahun 2000 orang Indonesia semakin banyak yang mengunjungi Tiongkok, salah satunya adalah untuk melakukan bisnis. Hal ini tidak lain disebabkan sejak pemerintahan Presiden Abdurrahman Wahid (Gus Dur) yang mencabut Inpres Nomor 14 Tahun 1967 tentang pelarangan segala hal yang berhubungan dengan Tiongkok. Inpres tersebut dicabut dengan terbitnya Keputusan Presiden Nomor 6 Tahun 2000 pada 17 Januari 2000 (Galih, 2017)

Lebih murahnya barang produksi Tiongkok dibandingkan dengan barang produksi Indonesia, membuat para pelaku bisnis mencoba untuk melakukan impor langsung dari Tiongkok. Meskipun barang dari Tiongkok terkenal dengan kualitasnya yang kurang bagus, akan tetapi harga yang murah merupakan kekuatan yang membuat orang tetap bisa mempertimbangkan untuk membeli barang made in Tiongkok.

Beberapa tahun belakangan ini, di internet marak dijumpai iklan tentang bisnis tour atau seminar bisnis impor barang dari Tiongkok. Peminat dari bisnis tour ini bisa dikatakan tidak sedikit, dari kalangan remaja hingga orang dewasa, dari pedagang atau pebisnis ataupun orang biasa yang baru akan merintis usahanya.

Salah satu yang menarik dari bisnis tour ini adalah ditawarkannya tour ke Tiongkok untuk mengunjungi pusat grosir 
(wholesale market), pabrik, pameran ekspor-impor, melakukan analisa pasar, cara memilih supplier, dan cara mengirimkan barang sampai ke Indonesia.

\section{METODE}

Penelitian ini menggunakan metode observasi tidak berstruktur dan tinjauan pustaka. Sugiyono (2012:312) mengatakan bahwa observasi tidak berstruktur adalah observasi yang tidak dipersiapkan secara sistematis tentang apa yang akan diobservasi. Hal ini dilakukan karena peneliti tidak tahu secara pasti tentang apa yang akan diamati. Dalam melakukan pengamatan peneliti tidak menggunakan instrumen yang telah baku, tetapi hanya berupa rambu-rambu pengamatan. Observasi dilakukan saat penulis menjadi tour guide di Guangzhou dan Shenzhen serta menganalisa pasar di pusat grosir Kota Yiwu, Provinsi Zhejiang. Selain itu, juga dilakukan analisa terhadap website yang menawarkan jasa bisnis tour di Indonesia. Sementara itu, tinjauan pustaka dilakukan dengan mengumpulkan data dari internet, buku, karya ilmiah maupun media cetak.

\section{Hasil dan Pembahasan Kota Shenzhen}

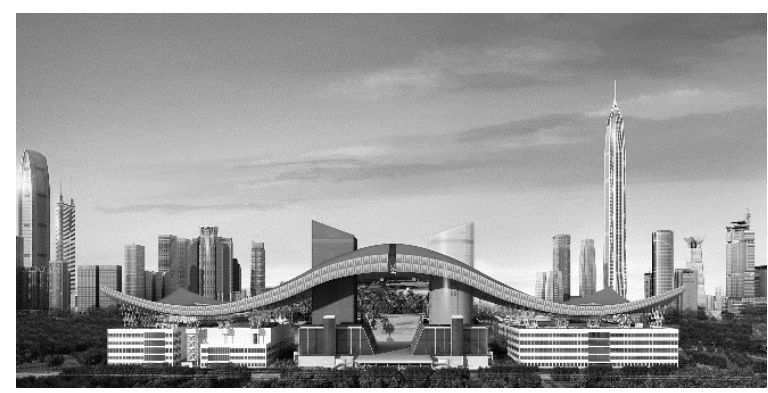

Gambar 1. Shenzhen central government building Sumber http://www.sz.gov.cn/cn/

Shenzhen terletak di ujung selatan daratan Tiongkok dan di tepi timur Sungai
Mutiara (Pearl River), tepatnya 150 kilometer sebelah tenggara Kota Guangzhou. Zona ekonomi khusus pertama di negara ini adalah gagasan pemimpin Tiongkok, Deng Xiaoping yang diterapkan pada tahun 1980. Sejak saat itu, Shenzhen telah menjadi batu ujian bagi reformasi Tiongkok dan kebijakan politik terbuka. Hanya dalam waktu 36 tahun, Shenzhen yang dulu hanya merupakan kota perbatasan kecil dengan penduduk sekitar 30.000 orang, telah berkembang menjadi kota metropolis modern. Hal ini merupakan sebuah pengalaman pertama dalam sejarah industrialisasi, urbanisasi dan modernisasi dunia.

Letak Shenzhen yang berdekatan dengan Hongkong memungkinkan banyak pedagang dari Tiongkok daratan yang melewati Shenzhen menuju Hongkong. Karena banyaknya orang yang lalu lalang melintasi kota ini, lama kelamaan orangorang mulai menetap di kota tersebut sehingga lambat laun semakin banyak pula yang menghuni Kota Shenzhen.

Shenzhen merupakan pusat teknologi tinggi dan manufaktur di Tiongkok Selatan, rumah bagi pelabuhan kontainer tersier tersibuk ketiga di dunia dan bandara tersibuk keempat di daratan Tiongkok. Kota ini adalah salah satu destinasi wisata populer di Tiongkok, juga terpilih sebagai salah satu dari 10 kota besar di Tiongkok yang populer dengan ekspatriat pada tahun 2015. Teknologi tinggi, jasa keuangan, logistik modern dan industri budaya menjadi andalan kota ini.

\section{Kota Guangzhou}




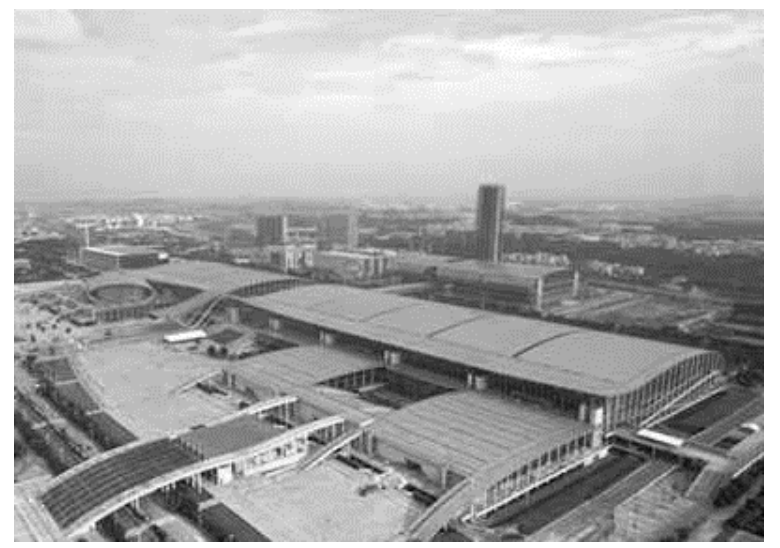

Gambar 2. Distrik Pazhou, Guangzhou

Sumber: https://www.cantonfair.net/

Guangzhou atau dikenal dengan sebutan Canton merupakan ibukota Provinsi Guangdong. Sebagai tanah kelahiran jalur sutra maritim di Tiongkok, Guangzhou selalu menjadi kota pelabuhan yang penting. Kota ini memiliki ekonomi dan perdagangan yang makmur, juga membuka tangannya kepada para pedagang dari seluruh dunia. Tiga pelabuhan besar yang terkenal di Guangzhou yaitu pelabuhan Guangzhou, Huangpu dan Nansha. Guangzhou adalah kota terbesar ketiga di Tiongkok setelah Beijing dan Shanghai. Kota ini memiliki sepuluh distrik, dan hampir semuanya memiliki pusat grosir.

Guangzhou juga merupakan salah satu pusat perdagangan internasional hingga saat ini. Sejak tahun 1957 di Guangzhou terdapat pameran ekspor impor terbesar di Tiongkok, yaitu Canton Fair atau dalam bahasa Mandarin disebut " 广交会guăng jiāo huì". Canton Fair diadakan dua kali dalam setahun, musim semi dan musim gugur. Musim semi biasanya diadakan pada Bulan April sampai Mei, sedangkan musim gugur diadakan pada Bulan Oktober hingga November. Setiap musim dibagi tiga sesi dan setiap sesi memamerkan kategori komoditas yang berbeda-beda.
Pameran ini diadakan di Pusat Pameran Internasional Pazhou, merupakan pusat pameran internasional terbesar dengan fasilitas paling mutakhir dan desain pameran dengan tingkat kegunaan tertinggi di Asia. (“Pazhou..", n.d, para. 1)

\section{Kota Yiwu}

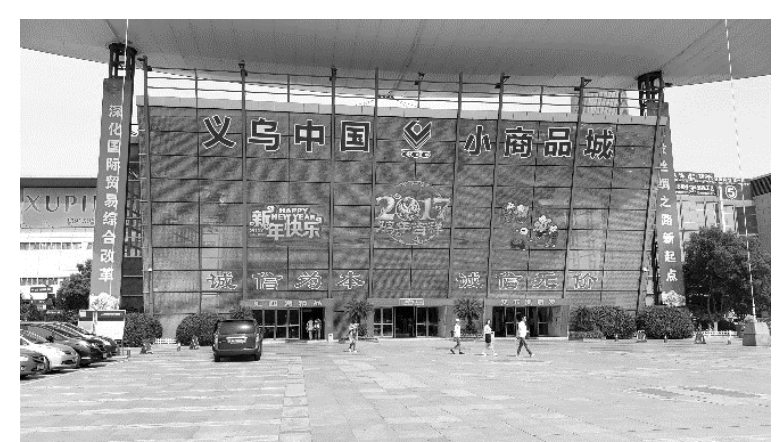

Gambar 3. Yiwu International Trade Market Sumber: Dokumentasi Penulis

Yiwu, terletak di bagian tengah Provinsi Zhejiang, mencakup area seluas $1.105 \mathrm{~km}$ persegi dengan enam kota dan tujuh kecamatan. Yiwu memiliki 739ribu penduduk lokal dan lebih dari satu juta pekerja migran sampai akhir tahun 2010. Sejak masa reformasi dan kebijakan politik pintu terbuka, masyarakat Yiwu telah menempuh jalan pembangunan daerah dengan karakteristik sendiri dengan berpegang pada strategi "membangun kota dengan memakmurkan perdagangan" .

Saat ini, pasar komoditas kecil Yiwu memiliki luas 2.6 juta meter persegi, memiliki 58.000 toko, mengumpulkan lebih dari 0,4 juta produk di bawah 1.900 kategori dalam 43 industri. Komoditas pasar Yiwu telah diekspor ke 215 negara dan wilayah di seluruh dunia.

\section{Bisnis Tour}

Sejak majunya perekonomian Tiongkok dalam berbagai bidang, 
membuat banyak negara tertarik untuk belajar, berwisata maupun berbisnis ke Tiongkok tidak terkecuali Indonesia. Semakin banyak orang yang mencoba berdagang dengan membeli barangbarang dari Tiongkok. Namun bagi bisnis pemula, terfikir kendala-kendala yang akan dihadapi saat berbisnis dengan orang Tiongkok. Kendala tersebut misalnya ketidaktahuan lokasi pusat grosir, bahasa saat tawar menawar harga, cara memilih supplier, cara pengiriman barang dan lain sebagainya. Seiring dengan hal itu, mulai banyak penawaran jasa agen untuk membantu para pemula dan pebisnis mengatasi kendala tersebut dengan pendampingan melalui bisnis tour. Tujuan utama dari bisnis tour ini yaitu mengunjungi tempat produksi (pabrik) maupun pusat perdagangan grosir, pameran ekspor impor, cara melakukan pengiriman barang ke Indonesia serta melakukan pemesanan barang secara langsung. Karena semakin banyak peminat terhadap bisnis tour ini maka makin banyak pula agen bisnis tour yang menawarkan untuk menjadi mentor atau mengantarkan ke Tiongkok, baik hanya untuk melihat-lihat pasar, mengunjungi pabrik, mencari ide untuk berbisnis, maupun mencoba langsung berbelanja dalam kuantitas sedikit atau banyak.

Lama waktu yang ditawarkan dari bisnis tour ini biasanya antara lima hingga sepuluh hari. Harga yang diberikan oleh agen tourj uga bervariatif, dengan tujuan kota yang berbeda pula. Harga paket bisnis tour ini berkisar dari 4,5 juta hingga 20 juta. Kisaran harga tersebut dapat berubah jika ada permintaan khusus dari perorangan atau sekelompok orang yang mempunyai tujuan tour berbeda dari yang telah dijadwalkan. Perbedaan harga paket tour ini terletak pada fasilitas yang diberikan.
Paket bisnis tour dengan harga 4,5 juta tidak termasuk tiket pesawat pulang pergi, hotel, visa dan makan. Sementara itu, paket dengan harga yang lebih mahal biasanya termasuk biaya tiket pesawat pulang pergi Jakarta-Tiongkok, pengurusan visa single entry, tour guide, hotel, makan, kartu SIM card Tiongkok, tiket masuk Canton Fair (jika ada agenda tujuan ke Canton Fair), dan pengurusan ID Canton Fair.

Destinasi tujuan tour bisnis ini juga beragam, ada yang menawarkan untuk mengunjungi pabrik, wholesale market hanya di satu kota saja, misalnya selama enam hari hanya di Yiwu dengan jadwal yang telah diatur pihak agen. Namun ada juga agen tour yang menawarkan paket bisnis tour ke dua atau tiga kota di Tiongkok sekaligus dalam enam hari tujuh malam, yaitu Shenzhen-Yiwu atau Guangzhou, Shenzhen dan Yiwu. Selain penawaran tersebut, juga ada yang menawarkan paket tour dalam waktu sepuluh hari. Paket bisnis tour yang lain yaitu khusus mengunjungi pameran ekspor-impor Canton Fair, Guangzhou. Paket tour ini diberikan selama lima atau enam hari dengan hanya mengunjungi pameran Canton Fair saja. Meskipun demikian, karena komplek pameran yang luas dan barang yang sangat beragam, waktu selama enam hari pun akan terasa sangat kurang. Saat pameran Canton Fair, biasanya produsen atau distributor dari seluruh Tiongkok banyak yang mengikuti expo ini, sehingga sangat memudahkan pelaku bisnis untuk menghemat waktu. Alasannya yaitu karena untuk mencari produk-produk yang diinginkan tidak perlu repot pergi ke tempat yang berbeda di seluruh Tiongkok.

Tempat tujuan tour bisnis hanya sebatas tiga kota, Guangzhou, Shenzhen 
dan Yiwu. Hal ini dikarenakan ketiga tempat tersebut merupakan pusat wholesale market yang terkenal di Tiongkok. Sebagai contoh, di bawah ini merupakan beberapa tujuan bisnis tour yang biasa dikunjungi saat di Guangzhou, yaitu:

a. Yide Road一德路（yī dé lù）. Tempat ini merupakan pusat grosir mainan, segala pernak-pernik dan aksesoris yang terlengkap di kota Guangzhou. Yide road terletak di Distrik Yuexiu. Selain menggunakan taksi, tempat ini juga bisa dijangkau menggunakan alat transportasi umum lain yaitu bus dan kereta bawah tanah atau biasa disebut 地铁 (ditiě). Harga barang yang ditawarkan di tempat ini merupakan harga grosir, sehingga jika membeli barang dengan harga eceran akan mendapatkan harga yang lebih tinggi.

b. Zhanxi Road 站西路 (zhàn xī lù) . Selain Yidelu, terdapat pusat grosir sepatu, sandal, baju bola, topi, pakaian laki-laki dan wanita, pakaian dalam, serta jam tangan yang cukup terkenal di Guangzhou. Barang yang dijual di tempat ini bisa merupakan barang bermerek, merek asli Tiongkok, atau dapat memesan label sesuai dengan kehendak pembeli. Beralamat di jalan Zhanxi Road, Distrik Yuexiu, tempat ini mulai buka pukul 11.00 pagi hingga sore pukul 18.00 waktu Tiongkok. Zhanxi Road merupakan pusat grosir yang ramai dikunjungi wisatawan asing dari berbagai negara, diantaranya Malaysia, Thailand, Filipina, Indonesia, Pakistan, dan berbagai negara Timur Tengah dan juga benua Afrika.

c. Guihuagang Leather Market 桂花岗（ guìuā gāng) , merupakan pusat grosir tas terbesar di Kota Guangzhou. Barang yang dijual di tempat ini diantaranya tas kerja laki-laki maupun perempuan, tas pesta, tas sekolah, ransel, koper, dompet, dan ikat pinggang. Bahan dari barang tersebut bisa dari kulit asli maupun sintetis. Barang yang dijual di tempat ini mulai dari barang kualitas paling rendah hingga kualitas premium.

\section{d. Baima Clothes Market白马服装城} báimă fúzhuāng chéng) . Pusat grosir selanjutnya adalah Baima Clothes Market yang merupakan tempat dimana bisa ditemukan bermacam-macam pakaian baik wanita maupun pria, T-shirt, pakaian kerja, baju Korea dan lain sebagainya. Letaknya yang sangat dekat dengan stasiun kereta api Guangzhou membuat tempat ini sangat mudah dijangkau oleh para pedagang dari seluruh penjuru Tiongkok.

e. Zhongda Fabric Market 中大布料市场 (zhōng dà bùliào shìchăng), tempat ini merupakan pusat kain, garmen, alat jahit, kancing baju dan segala macam aksesoris pakaian. Tempat dengan area yang luas membuat pengunjung tidak cukup mengunjungi tempat ini dalam tiga hari.

Kelima tempat di atas adalah contoh pusat grosir yang dikunjungi di Guangzhou. Masih banyak tempat yang dapat dikunjungi, tergantung pada kebutuhan masing-masing. Misalnya pusat grosir kosmetik, alat kesehatan, spare part motor atau mobil, baju anak, alat tulis kantor, perlengkapan hotel, lampu, kamera atau CCTV, alat elektronik, furniture, handphone dan lain sebagainya.

Kota Shenzhen mempunyai banyak wholesale market, komoditas yang ditawarkan hampir sama dengan Kota Guangzhou namun karena kota ini merupakan pusat teknologi dan manufaktur di Tiongkok Selatan, maka untuk bisnis tour biasanya ditawarkan mengunjungi pabrik elektronik atau hanya melakukan survei pusat grosir elektronik. 
Salah satu pusat grosir elektronik terbesar di Kota Shenzhen adalah Huaqiangbei Market 华强北（huáqiáng běi）. Tempat tersebut memiliki beberapa gedung pusat perbelanjaan khusus elektronik yang menjual barang seperti handphone dan aksesorisnya, sparepart dan aksesoris komputer, kamera, speaker, earphone, dan alat elektronik lainnya.

Situasi pasar grosir Kota Yiwu berbeda dari Guangzhou dan Shenzhen. Kota ini terkenal dengan pasar grosir komoditas kecilnya. Pada tahun 2005, Perserikatan Bangsa-Bangsa, Bank Dunia dan Morgan Stanley menyebutkan dalam laporan bersamanya "figur Tiongkok yang mencengangkan dunia", bahwa pasar komoditas kecil Yiwu adalah pasar grosir komoditas terbesar di dunia. Pasar komoditas kecil Yiwu memiliki luas 2.6 juta meter persegi, memiliki 58.000 toko, mengumpulkan lebih dari 0,4 juta produk di bawah 1.900 kategori dalam 43 industri. Jika seseorang menghabiskan waktu lima menit pada setiap toko, maka akan membutuhkan waktu hampir dua tahun untuk menjelajahi kompleks pasar ini.

Pasar komoditas kecil tersebut bernama Yiwu International Trade Market 义乌国际商贸城（Yìwū guójì shāngmào chéng). Pasar ini dibagi menjadi lima distrik dimana komoditas yang dijual pada setiap distrik berbeda satu dengan yang lain. Setiap distrik memiliki rata-rata empat lantai.

Distrik 1 dibagi dalam dua bagian, distrik 1 dan distrik 1 timur. Komoditas yang dijual pada distrik 1 antara lain: mainan, bunga imitasi, boneka, bross, aksesoris wanita, barang seni, barang dekorasi rumah, barang aksesoris perayaan, komoditas impor Taiwan, dan lain-lain. Distrik 1 timur menjual barang seperti gelang dan aksesoris fashion.
Komoditas yang ditawarkan di distrik 2 antara lain: tas, payung, lampu, kunci, sepeda, alat pertukangan, alat dapur, jam dinding, elektronik, baterai dan lain-lain.

Pada distrik 3 tersedia komoditas seperti alat tulis kantor, kaca mata, perlengkapan olahraga tradisional dan modern, kosmetik dan peralatannya, lukisan, perlengkapan Imlek dan lain-lain.

Distrik 4 menyediakan sepatu, topi, sarung tangan, penutup telinga, handuk, benang wol, dasi, pakaian dalam, sabuk, syal, baju, bingkai, dan lain-lain.

Pada distrik terakhir tersedia seprai dan selimut, alat keperluan rambut, perlengkapan pesta pernikahan, gorden, aksesoris dan suku cadang otomotif, perlengkapan hewan peliharaan, kain rajutan, bahan baku tekstil dan berbagai macam komoditas impor.

Agen bisnis tour langsung menuju komplek perdagangan internasional ini dengan sistem pasar grosir terpusat. Setelah tour berjalan selama dua sampai tiga hari, biasanya akan disediakan waktu khusus satu hari untuk tour opsional ke Kota Shanghai, mengingat Kota Yiwu letaknya dekat dengan Shanghai. Hanya memerlukan waktu dua jam saja untuk menuju Shanghai dengan menggunakan kereta cepat.

Pendampingan bisnis tour ini tidak hanya saat di Tiongkok saja, namun masih dibimbing saat sampai di Indonesia. Bimbingan ini yaitu sharing tentang cara pemasaran produk di Indonesia baik melailui online maupun offline. Peminat dari bisnis tour ini rata-rata adalah para pelaku bisnis yang awalnya penasaran dan ingin mengetahui murahnya barang di Tiongkok. Selain itu, mereka juga ingin melihat pusat grosir secara langsung, praktek bernegosisasi serta ingin membeli 
barang langsung dari tangan pertama atau produsen di Tiongkok. Dengan demikian, pelaku bisnis bisa mendapatkan untung yang lebih besar daripada jika membeli barang dari pasar grosir di Indonesia.

\section{KESIMPULAN}

Bisnis tour beberapa tahun ini sedang menjadi tren di Indonesia. Hal ini tidak lepas dari majunya perekonomian Tiongkok dan pengaruh masuknya pasar bebas Masyarakat Ekonomi Asia (MEA). Tujuan dari bisnis tour ini adalah untuk mengunjungi pabrik atau wholesalemarket di Tiongkok serta analisa harga dan pasar. Destinasi tujuan dari bisnis tour ini di tiga kota di Tiongkok, yaitu Guangzhou, Shenzhen dan Yiwu. Harga yang ditawarkan dari bisnis ini bervariatif berdasar fasilitas yang diberikan oleh agen bisnis tour. Dampak positif yang bisa disimpulkan dengan adanya bisnis tour ini yaitu banyak perintis bisnis yang bisa mandiri dan mendapatkan kemudahan untuk berbisnis, sehingga dapat mengurangi dominasi kartel di Indonesia. Hal ini juga merupakan sebuah pemerataan kesempatan menjadi importir, memberi kesempatan kepada pedagang kecilmenengah untuk lebih maju dalam bidang bisnis impor. Di samping hal diatas, bisnis tour ini merupakan hal baru yang bisa dikembangkan dalam dunia tour and travel di Indonesia. Dampak negatifnya yaitu dengan banyaknya orang yang impor barang langsung dari Tiongkok, membuat persaingan harga yang tidak sehat di pasaran.Harga jual produk cenderung cepat jatuh dan dapat mematikan industri kecil dalam negeri.
Chai May-Lee and Chai Winberg, 2015. China A to Z. New York: Plumel

Economy. n.d. Guangzhou Government. Diakses dari http://english.gz.gov.cn/gzgoven/s3616 /201508/7550e7ddda96487a910527987 4e8097a.shtml

Galih, B. (2017, Januari 30). Peran Gus Dur di Balik Kemeriahan Imlek... diakses dari http://nasional.kompas.com/read/2017/ 01/30/06060031/peran.gus.dur.di.balik. kemeriahan.imlek

General Situation of Yiwu. N.d. Yiwu Government. Diakses dari http://yw.gov.cn/english/english_1/e_g yyw/e_ywgk/ywgk

Mahmudi, 2013. Penuntun Penulisan Karangan Ilmiah: Untuk Mahasiswa, Guru, dan Umum. Yogyakarta: Aswaja Pressindo

Pazhou Internasional Convention and Exhibition Center, n.d. Guangzhou Internasional diakses dari http://english.gz.gov.cn/gzgoven/s897 4/201105/804387.shtml

Pendit, Nyoman. S. 2005. Glosari Pariwisata Kontemporer : Memperkaya Kazanah Industri Hospitaliti \& Perjalanan wisata Indonesia. Jakarta: Pradnya Paramita

Mitler, Rana. 2011. China Modern Menguasai Dunia. Yogyakarta: Pustaka Pelajar

Origin of City's Names. n.d. Guangzhou Internasional diakses dari http://english.gz.gov.cn/gzgoven/s3616 /rlist.shtml

Overview. N.d. Szenchen Government. Diakses dari http://english.sz.gov.cn/gi/

Sugiyono, 2012. Metode Penelitian Kombinasi (Mixed Methods). Bandung: Alfa Beta

\section{Daftar Pustaka}

